\title{
Automatic Transfers and the Money Supply Process
}

\author{
JOHN A. TATOM and RICHARD W. LANG
}

\begin{abstract}
S
WINCE November 1, 1978, commercial banks have been permitted to offer a new type of individual savings account from which funds are transferred automatically into a checking account. This automatic transfer service (ATS) enables individual customers to earn interest on funds which previously would have been held in their checking accounts. The use of these new ATS accounts affects the payments system and the money supply process. ${ }^{\mathrm{I}}$ Since some checkable balances can be held in sav. ings accounts while other checkable balances will continue to be held in demand deposit accounts, ATS alters the interpretation of existing measures of monetary aggregates.
\end{abstract}

The use of these new savings accounts will change the relationship between Federal Reserve actions and conventional measures of monetary aggregates. The ATS innovation will reduce the responsiveness of the

\footnotetext{
An historical perspective on the development of ATS is provided by Alfred Broaddus, "Automatic Transfers from Saving: to Checking: Parspective and Prospects," Federal Reserve Bank of Richmond Economic Review (November/December 1978), pp. 3-13. Some of the difficulties posed by ATS are also discussed by Scott Winmingham, "Altonatic Transfers and Monetary Policy," Federal Reserve Bank of Kansas City Econonic Review (Novernot 1978), pp. 18.27.
}

most widely reported aggregate, M1 (the sum of currency plus demand deposits), to Federal Reserve actions. At the same time, broader measures of monetary aggregates will become more responsive to Federal Reserve actions. Understanding these effects is essential both for analysts who study the impact of monetary aggregates on inflation and economic activity, and for policymakers who require a knowledge of the relationships between their actions and the objectives of policy.

The importance of these conclusions for the implementation and interpretation of monetary policy actions can be simply stated. During the adjustment period over which individuals rearrange the pattern of account holdings at commercial banks, MI will grow slower and broader monetary aggregates will grow faster than they otherwise would have. Therefore, existing measures of these aggregates may provide conflicting signals of the direction of monetary actions and their prospective impact on the economy.2

2The staff of the Board of Govemors of the Federal Reserve Systen recently proposed a redefinition of the monetary aggregates which, if adopted, would tend to alleviate some of these difficulties. See "A Proposal for Redefining the Monetary Aggregates," Federal Reserve Bulletin (Jantary 1979), pp. 13442. 


\section{ATS DEPOSTTS AND MONETARY AGGREGATES}

An individual may open (or add to) a savings account with the ATS feature by using existing financial assets such as deposit balances held in demand or savings accounts. ${ }^{3}$ For example, the individual may transfer funds from a demand deposit account. Although the individual may consider his total of checkable deposits or transaction-related balances to have remained the same, measured demand deposits (a component of M1) will fall, while ATS savings deposits (not a component of M1) will rise. Thus, M1 will fall. Since savings balances and demand deposit balances are both included in $\mathrm{M} 2$, it is not affected immediately by such a transaction.

The commercial banking system will be affected beyond the mere relabeling of the account in which the individual holds checkable deposits. The required reserve ratio against demand deposits is higher than the ratio for time and savings (including ATS) accounts for member banks in the Federal Reserve System (see Table I). ${ }^{4}$ Thus, the transfer of funds from demand deposits to ATS deposits will reduce required reserves, allowing the banking system to increase loans, investments, and deposits.

If funds are transferred to an ATS account from an existing savings account at a commercial bank, there is no change in required reserves in the banking system, since the required reserve ratio is the same for both accounts. Since neither account is

\footnotetext{
3Throughout this paper, unless noted otherwise, it is assumed that there is no Federal Reserve policy reaction to the shift into ATS deposits. It also must be noted that the relevant changes in financial asset holdings concem changes in the desized proportions of demand deposits and other savings deposits at commercial banks to checkable deposits, defined to include ATS balances after November $1_{1}$ 1978. The source of the initial ATS deposit does not matter per se. This confusion easily arises when considering the Federal Reserve Board of Governors" surveys on the ATS experience which show that about 60 percent of ATS balances arise from demand deposits and 40 percent from other savings accounts. Such figures provide no information on the changes in the desired proportions in which various financial assets are held. For example, most tirne accounts are increased by the deposit of checks or currency. This does not mean that demand deposits or currency in the ecomomy decline when time deposits expand. If the public's desired ratios of time deposits and currency to demand deposits are unchanged, one individual's deposit to a time accomst ultimately has no effect on ML or M2. The individual transactions discussed are intended to represent changes in desired proportions of demand deposits or other time deposits to checkable deposits.
}

${ }^{4}$ Similar differential reserve requirements on demand and savings accounts exist in almost all states for nonmember commercial banks. See R. Alton Gilbert and Jean M. Lovati,

"Bank Reserve Requirements and Their Enforcement: A Com-

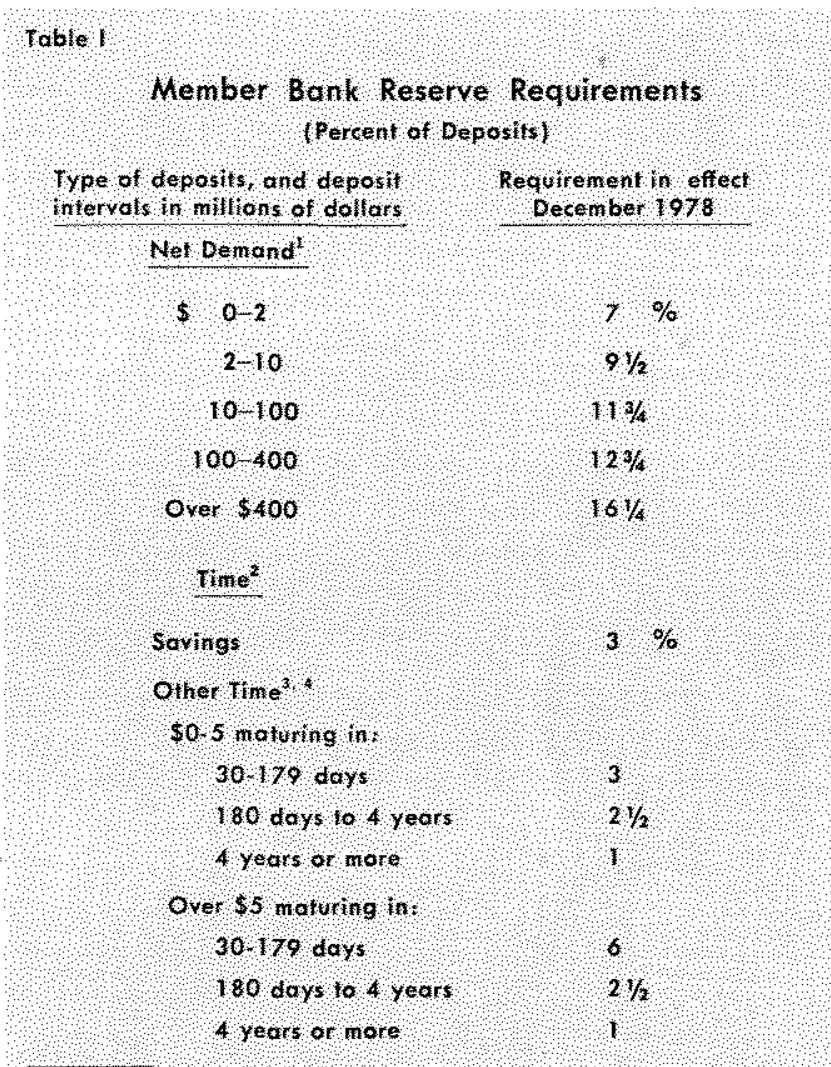

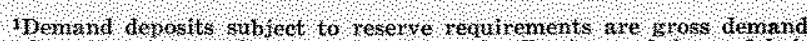

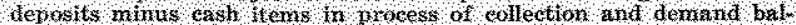
ances due from lomes te bants

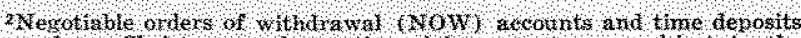

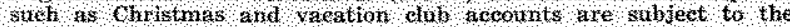
gane reounenerts wo sawngs depostis

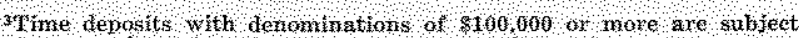
$6 a$ supplementary 2 pereent resente requirenent

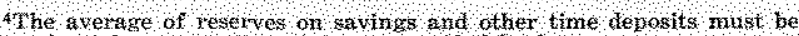
at lesst 3 gercent tfe ninimum sooffed by law

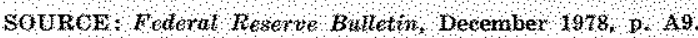

included in $\mathrm{M} 1$ and both are included in M2, there is no change in the monetary aggregate measures.

Thus, the introduction of the ATS feature affects the measures of monetary aggregates for both definitional and institutional reasons. The definitional reason is that ATS balances which individuals use to replace demand deposits are not included in M1;

parison Across States," this Review (March 1978), pp. 22-32. Changes in the menber/nonmember composition of deposits are ignored in this article.

If funds are withdrawn from a nonbank thrift institution, the result is quite different. In this case, the result is comparable to the switch from demand deposits to ATS accounts since the finds deposited in the ATS account are drawn upon the commercial bank demand deposit account of the nonbank thrift. In the unlikely event that other time deposits at commercial banks are transfored to ATS accounts, the results are aso different. Sinee ATS balances have higher required reserve ratios than most other time deposits, reserves are absorbed by such a transaction (see Table I). 
a transfer of balances from demand deposits to ATS savings deposits reduces $\mathrm{M} 1$. The institutional reason is that a given amount of ATS deposit bal. ances requires commercial banks to hold less reserves than an equal amount of demand deposit balances; a transfer of balances from demand to ATS savings accounts increases excess reserves. In response, commercial bank loans, investments, and deposits will rise. This increase in bank deposits will partly offset the reduction in $\mathrm{Ml}$, and will increase broader aggregates such as M2. Of course, the Federal Reserve could offset the increase in excess reserves caused by movements of funds from demand deposits to ATS accounts. In this case, excess reserves and broader monetary aggregates would be unchanged, but MI would still decline.

Another issue raised by the introduction of ATS accounts is its effect upon the interpretation of monetary aggregates. The sum of currency held by the public and demand deposits, M1, is generally considered a measure of the economy's medium of exchange, or financial assets which can be directly exchanged for goods and services. Since checks may be written against balances held in an ATS account, these balances should not be excluded from such a measure of financial assets. Consequently, it is useful to consider a third monetary aggregate measure which includes ATS balances as checkable deposits. ${ }^{6}$ In the model of the money supply process below, ATS balances are added to MI to form an aggregate denoted as $\mathrm{Ml}^{*}$. A recent proposal by the staff of the Federal Reserve Board of Governors includes ATS balances in a new $\mathrm{Ml}$ measure. The resulting measure would be very similar to the $\mathrm{Ml}^{*}$ used here. ${ }^{\top}$

Consider the effects of the introduction of ATS upon $\mathrm{Ml}^{*}$. While a transfer of funds from a demand

oIt may seem diffoult to obtain a measure of directly spendable dollar balances comparable to pre-ATS measures of $M 1$ since ATS accounts include balances held for the same reasons as other savings deposits, as well as balances held for transactions. The extent to which this classification diffeulty represents a problem for measuring and interpreting monetary aggregates is unclear, since it is not peculiar to the introduction of ATS. For example, minimum balances held to rednce service charges on demand deposit accounts are not held for transactions purposes to the same extent as other demand deposit batances. Yet there is no evidence that the inclusion of these "idle" balances in MI has affected the past usefuness of MI.

7 See Board of Governors of the Federal Reserve System, "Redefining the Monetary Aggregates." The proposed M1 measure excludes selected foreign deposit balanees which are currently included in M. The proposed MI measure also inchides NoW account balances, credit mion share draft balances, and other demand deposits at thrift institutions which are igrored in the discussion of $\mathrm{MI}^{*}$. deposit account to an ATS account lowers $\mathrm{Ml}, \mathrm{M1}^{*}$ initially is unaffected; the rise in ATS balances offsets the equal-sized decline in demand deposits. The reduction of required reserves resulting from this transfer allows commercial banks to expand their loans, investments, and deposits, so $\mathrm{M} 1^{\circ}$ will ultimately rise and the initial decline in $\mathrm{Ml}$ will be partially offset. As discussed above, this effect arises solely because of differential reserve requirements. Transferring funds from an existing savings account to ATS will increase $\mathrm{M1}^{*}$ while leaving $\mathrm{M} 1, \mathrm{M} 2$, and required reserves unaffected.

\section{ATS AND THE MONEY SUPPLY PROCESS}

A standard model of the money supply process can be modified to account for the effects of ATS on monetary aggregates. The central feature of the standard model is that individuals and banks demand currency and bank reserves while the available supply of assets which may be used for these purposes is controlled by the Federal Reserve System. ${ }^{8}$

The desired demand for currency relative to checkable deposits, expressed as a ratio ( $k$ ), depends upon such economic factors as the relative costs and benefits of holding and using the two assets for transactions. For example, checks are more safely and cheaply used for some transactions while currency has a relative advantage for others. Changes in the relative proportions of such transactions in total spending affect the desired ratio of currency holdings to checkable deposits. Currency holdings, $\mathrm{C}$, may be expressed as:

$$
\mathrm{C}=\mathrm{k} \mathrm{CD}
$$

where $C D$ represents checkable deposits and $k$ depends on an unspecified set of economic variables, which can be regarded as given for the purposes here.

The commercial banking system's holdings of currency and reserves depend primarily upon required

\footnotetext{
"In the usual model, the ratios discussed below are fenned relative to demand deposits instead of chockable deposits. The modifcation maintains continuity with older series on the relevant ratios since, before November 1, 1978, checkable deposits and demand deposits were vitually identical. Also, this change simplifies the arithmetic. In the usual model, AIS wond tend to raise the ${ }^{-}$and t-ratios and lower the r-ratio, as ATS balances replace demand deposits. These changes appear to have ambiguous effects on money multipliers. However, with considerable manipulation of the usmal model, the results below can be derived.
} 
reserve ratios of the Federal Reserve System. Commercial banks which are not Federal Reserve members are also subject to reserve requirements, but their reserves are held largely as demand deposits at other commercial banks and not as deposits at Federal Reserve Banks. Both member and nommember banks hold vault cash as a part of their reserves.

For simplicity, the demand for vault cash and reserves at Federal Reserve Banks ( $R$ ) can be attributed to the deposits against which reserves are held demand, other time and savings, and ATS deposits." The average required reserve ratio for member banks on all savings and time deposits is approximately the same as that for ATS deposits. It is assumed that the average reserve ratio on other time and savings de posits (T) and on ATS deposits (ATS) are the same, $r_{t}$, and equal the required ratio on savings deposits. The average reserve ratio on demand deposits (DD) is called $r_{d}$. Total reserves, $R$, can be expressed as:

$$
\mathbf{R}=\mathbf{r}_{\mathrm{a}} \mathrm{DD}+\mathrm{r}_{\mathrm{e}} \mathrm{i}+\mathrm{r}_{\mathrm{t}} \text { ATS }
$$

By dividing checkable deposits into its two components, demand deposits and ATS balances, each component may be measured as a fraction of checkable deposits. If the proportion of ATS balances to checkable deposits is called $d$, then the proportion of demand deposits is $(1-d)$. Similarly, other time and savings deposits may be expressed as a ratio of checkable deposits; this ratio is called t. Total reserves in equation (2) can be rewritten as:

$$
R=\left[r_{d}+r_{t} t-d\left(r_{d}-r_{t}\right)\right] C D=r C D
$$

where $r$ is the average reserve ratio, or in this case the ratio of total bank reserves to checkable deposits. Changes in the d-ratio may be used to analyze the impact of the introduction of ATS accounts.

Reserves of commercial banks and currency hold. ings of the public are limited by the existing supply of such assets. One measure of these assets is the monetary base which is adjusted for changes in member bank reserve requirements. Another is the source base which is not so adjusted. The source base is used here to simplify calculations, but the analytical

\footnotetext{
9U.S. government demand deposits at comnercial banks are not included in the demand deposit component of the money supply, but they are inchuded in commercial bank demand deposits for reserve requirement purposes. Thus, in the discussion here, these required roserves are inchuded in the ratio of total reserves to private demand deposits.
}

results and quantitative measures below are virtually identical using either measure of the base. ${ }^{10}$

Together with the definitions of various monetary aggregates, the source base and equations (1) and (2') provide a framework for analyzing the money supply process. In particular, any monetary aggregate (M) can be considered to be the product of a multiplier (m) and the base (B):

$$
\mathrm{M}=\mathrm{mB}
$$

This result follows from equating the uses of the base and its supply:

$$
\begin{gathered}
\mathrm{B}=\mathrm{C}+\mathrm{R}=\mathrm{kCD}+\mathrm{r} \mathrm{CD} \text { or } \\
\mathrm{CD}=\frac{1}{\mathrm{k}+r} \mathrm{~B}
\end{gathered}
$$

Monetary aggregates can be expressed using eqtation (5) and the ratios which relate the components of each aggregate to checkable deposits. For example, the narrow money supply is cumency ( $k$ CD) plus demand deposits $[(1-d) \mathrm{CD}]$ or:

$$
\mathrm{M} 1=\frac{(1-\mathrm{d})+\mathrm{k}}{\mathrm{k}+\mathrm{r}_{\mathrm{d}}+\mathrm{rt}_{\mathrm{t}}-\mathrm{d}\left(\mathrm{r}_{\mathrm{d}}-\mathrm{rt}_{\mathrm{t}}\right)} \mathrm{B}=\mathrm{ml} \mathrm{B}
$$

Within this framework, the introduction of ATS may be viewed as having an impact upon the money multiplier. For a given source base determined by Federal Reserve actions, a shift to ATS deposits changes a monetary aggregate measure by changing the multiplier.

Since a multiplier measures the link between Federal Reserve actions and each monetary aggregate, the effect of ATS on the size of a multiplier also determines its impact on the responsiveness of an aggregate to changes in the source base. If the multiplier for an aggregate rises, the aggregate is more responsive to a given Federal Reserve action which changes the source base. If the multiplier declines, the monetary aggregate changes less for a given change in the base.

Stuch changes in the responsiveness of aggregates to changes in the base are only likely to be significant during the period of transition to ATS. The rate of growth of an aggregate may be decomposed using equation (3) into the rate of growth of the base, $B$, and the rate of change of the mutiplier, $m$.

\footnotetext{
rosee Albert E. Burger and Robert H. Rasche, "Revision of the Monetary Base," this Review (july 1977), p. 13, for a rationale for using the monetary base instead of the sonrce base in monetary analysis. Also, see Albert $\mathrm{E}$. Burger, The Money Supply Process (Belmont, Califomia: Wadsworth Publishing Co., Ine, 1971), pp. 38-39, 190
} 


\begin{tabular}{|c|c|c|}
\hline \multicolumn{3}{|c|}{ Money Multipliers } \\
\hline Aggregate & & Muitiplier \\
\hline M] & $m 1=$ & $(1-d)+k$ \\
\hline & & $k+r_{d}+r_{t} t-d\left(r_{t}+-r_{t}\right)$ \\
\hline $\mathrm{Ml}^{*}$ & $m 1^{*}=$ & $1+k$ \\
\hline & & $k+r_{d}+r_{t}+\cdots d\left(r_{t}-r_{t}\right)$ \\
\hline $\mathrm{M2}$ & $m^{2}$ & $1+k+k$ \\
\hline
\end{tabular}

Since the change in the multiplier will occur only during this period of transition, ATS will have no impact on the responsiveness of aggregates to base growth after the adjustment to ATS is complete. ${ }^{11}$

The money multipliers for $\mathrm{M} 1, \mathrm{M} 2$, and $\mathrm{M}^{*}$ are given in Table II. In the absence of ATS accounts, the d-ratio is zero and the multipliers are those of the usual model. Note that in this case $k$ and $t$ are ratios measured relative to demand deposits only, Also, in deriving the M2 expression, only a portion of time deposits is included, representing the ratio of other net time deposits to checkable deposits $\left(t_{1}\right)$; large negotiable certificates of deposit at weekly reporting large banks are included in $t$ but not in the definition of M2.

The effects of the introduction of ATS accounts on each of the monetary aggregate measures can be demonstrated using the multipliers in Table Il. The effects on the various multipliers due to a change in $\mathrm{d}$ are shown in the first column of Table III."2 The signs indicate that a rise in ATS savings deposits from zero to some proportion of checkable deposits, $\mathrm{d}$, unambiguously reduces the M1 multiplier while increasing the $\mathrm{M} 2$ and $\mathrm{M}^{\circ}$ multipliers. The latter two results arise solely because of the difference in average reserve ratios for demand deposits and savings deposits. If reserve requirements were the same on demand and ATS deposits, the only effect of an in-

\footnotetext{
11A second and more important isste for monetary control is the variability of the money multipliers. If the multiplier becomes more variable due to the introduction of ATS acw counts, the ability to control monetary aggregates is rediced. Because movements of funds between ATS aceounts and demand deposits are likely to increase the variability of average reserve holdings due to differential reserve requirements, reduced control is to be expected, other things being equal.

${ }^{12}$ It is assumed here that all ATS balances are theckable balances held for transactions purposes. The effects of relaxing this assumption are discussed below.
}

crease in the proportion of checkable balances held in ATS accounts would be a reduction in M1.

The second column of Table III provides expressions for the responsiveness of the aggregates to a change in the d-ratio. In each case the responsiveness is expressed by a measure (called a semi-elasticity) of the percentage change in the aggregate for each one percentage point rise in the d-ratio. These measures may be used to assess the impact of ATS on the aggregates as $d$ increases from zero to the level which individuals desire.

The results in Table III are derived assuming that the ratios $r_{i}, r_{t}, t$, and $k$ are unaffected by the introduction of ATS accounts. This assumption about the reserve ratios is motivated by the close relationship between average and required reserve ratios, which would not necessarily be expected to change due to ATS accounts. The currency ratio ( $k$ ) may fall, however, if the rate of return on checkable deposits increases substantially due to ATS. If the currency ratio declines, the tendency for $\mathrm{M1}^{*}$ and $\mathrm{M} 2$ to rise would be reinforced while the decline in Ml would be offset to some extent. ${ }^{13}$ A substantial rise in the rate of return on checkable deposits is not an obvious result of the introduction of ATS, however. While checkable deposits held in ATS accounts will earn a positive and explicit rate of interest, it is not clear that this rate will significantly exceed the implicit rate of return previously available on demand deposit accounts. If commercial banks had found it feasible to offer a substantially higher rate of return on checkable deposits prior to November 1, 1978, competitive pressures presumably would have forced them to do so through greater service charge remission or other methods.

The assumption that the ratio of other savings and time deposits to checkable deposits is unaffected by ATS may be questioned also. The presumption here is that all ATS balances are checkable balances held for transactions purposes. To the extent that ATS balances replace other savings balances, the t-ratio would decline during the transition to ATS. Again, such a development would reinforce the $M 1^{*}$ result, while partially offsetting the decline in Ml. However; a decline in the t-ratio would partially offset the tendency for 112 to rise. Viewed in light of these qualifications, the expressions in Table III can be considered to provide a minimum estimate of the increase in $\mathrm{MI}^{*}$

\footnotetext{
13 This requires that $(r+d)$ is less than me, which is the case given curyent values of $r$ and values of $d$ considered below.
} 
$\mathrm{Hal} \mathrm{ll}$

The Effects of ATS

Efferton the Multipher for 2

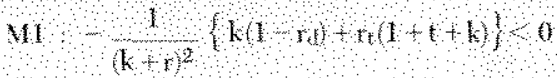

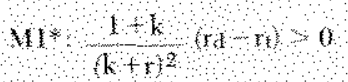

$\left.12 \frac{1+\mathrm{k}+\mathrm{h}}{(\mathrm{k}+\mathrm{r})^{2}} \mathrm{rl}\right)$

The Perentage Change in the Monetary A sentgate

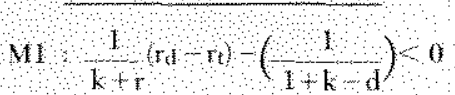

$\mathrm{M}+1 \mathrm{rarl} \theta 0$

$\mathrm{N} 2 \frac{1}{\mathrm{k}} \mathrm{rd} \mathrm{rl}$

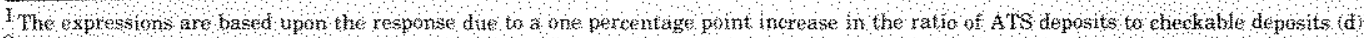

2 gists requed $1 \mathrm{rd}$

and a maximum estimate of the decline in MI which would result from the transition to ATS."

\section{ESTIMATES OF THE TMPACT OF ATS ON THE MONETARY AGGREGATES}

It is possible to provide general estimates of the impact of ATS on the monetary aggregates by evaluating the semi-elasticity expressions in Table III. The results provide a measure of the percentage change in each aggregate due to each one percentage point rise in $d$, other factors remaining the same.

In October 1978 the average values of the t-ratio, k-ratio, and rratio were $2.249,0.360$, and 0.158 , respectively. ${ }^{15}$ Since ATS accounts did not exist prior to November, the ratios are measured relative to demand deposits only $(d=0)$. Letting $r_{i}$, the average reserve ratio on time and savings deposits, equal

\footnotetext{
14If some fraction, $f$, of ATS balances is held for transactions purposes while the remainder is held for savings purposes, the results are similar to those obtained in Table III. In this case, only $\delta$ (where $\delta=\mathrm{fd}$ ) of ATS balances should be in cluded in checkable deposits and in MI". Also, the appropriate t-ratio in the model is $\tau=t+(J-f) d$. This mode results in expressions which are the same as in Tables II and III exeept that $\delta$ and $\tau$ replace $d$ and $t$, respectively. When the sembelasticities for $\mathrm{M} 1$ and $\mathrm{M} 2$ are measured relative to $d$, the expressions in Table III must be multiplied by $f$. The semi-elasticity for M1 (defined to include all ATS balances) for an observed change in $d$ is nore complicated. The semeelasticity in Table III is again multiplied by $f$, but ( 1 -.. f) $[1 /(1+k)]$ must be added to obtain the relevant semielasticity for $\mathrm{M}^{\circ}$

15The r-ratio is calculated by dividing the sum of member bank reserves and nommember bank vault cash by the demand deposit component of the money supply. The measures of the ratios are not very sensitive to the month or quarter chosen. For example, if the average monthly ratios for the year ending in October 1978 or for the third quarter of 1978 are used, the estimates of the effects on $\mathrm{M} 1, \mathrm{M} 2$, and $\mathrm{Ml}^{\circ}$ given below are the same.
}

3 percent, the average reserve ratio on demand deposits is found to be $0.091(r-r, t)$. When these parameters are used to evaluate the semi-elasticities in Table 111 , the results for $\mathrm{M} 1, \mathrm{Ml}^{*}$, and $\mathrm{M} 2$ are $-0.618,0.118$, and 0.118 , respectively, ${ }^{16}$ Thus, each one percent of checkable deposits held in ATS savings accounts reduces $\mathrm{Ml}$ by 0.62 percent, while increasing both $\mathrm{MI}$ and $\mathrm{M} 2$ by 0.12 percent, other factors remaining the same.

Table IV presents changes in the growth rates of $\mathrm{M} 1, \mathrm{M1}^{\circ}$, and $\mathrm{M} 2$ for various percentage shifts of eligible demand deposits into ATS deposits (assum. ing unchanged growth rates for the source base and for other factors influencing the growth rates of the monetary aggregates). When ATS accounts were introduced, about $\$ 95$ billion of demand deposits held by individuals were eligible for use in ATS plans. These eligible deposits have averaged about 34 percent of total demand deposits during 1977 and 1978. (The percentage shifts in terms of total demand deposits are shown in parentheses in Table IV). The level of $\mathrm{d}$ is obtained by multiplying the percentage of eligible demand deposits which will be held in ATS deposits (ranging from 5 to 30 percent in Table IV) by 34 percent. For example, if 5 percent of eligible demand deposits are held in ATS balances, the percentage of total demand deposits, $d$, is only 1.7 percent. The change in the growth rate of a monetary aggregate is obtained by multiplying $\mathrm{d}$ by the semi-elasticity of the money multiplier with re-

\footnotetext{
16 The semi-elasticity for Ml. is calculated with d set equal to zero, its initial value in this case. An altemative approach wonld be to calculate this semi-elasticity with $d$ set equal to its assumed value at the end of the period. This wonld result in a slightly larger (in absolute value) calculated semi-elasticity for Ml. For the values of a considered below, this altemative approach has little effect on the reported restults.
} 


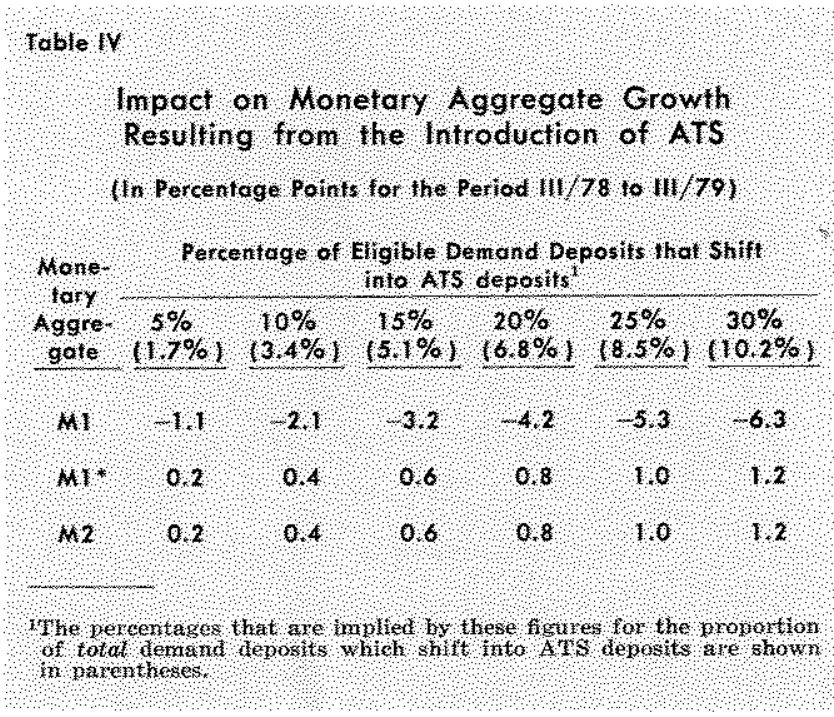

spect to d. Consequently, Ml would be reduced by about 1.1 percent $(1.7 \times-0.62)$ in this example. In Table IV it is assumed that the transition to ATS occurs over a one-year period, measured from the third quarter of 1978 to the third quarter of 1979.

While a 5 percent shift of eligible demand deposits reduces M1 growth by 1.1 percentage points over a one-year transition period, the growth of both $\mathrm{Ml}^{*}$ and $\mathrm{M} 2$ is increased by only 0.2 percentage points (Table IV). As the percent of eligible demand deposits held in ATS accounts increases, the reductions in M1 growth and the increases in $\mathrm{Ml}^{*}$ and $\mathrm{M} 2$ growth become larger. A shift of 30 percent of eligible demand deposits reduces $M 1$ growth by 6.3 percentage points over a one-year transition period, while both $\mathrm{M}^{\circ}$ and $\mathrm{M} 2$ growth are increased by 1.2 percentage points.

One estimate of the possible effects of the introduction of ATS accounts on the growth rates of $\mathrm{M1}$. $\mathrm{Ml}^{*}$, and $\mathrm{M} 2$ over a one-year transition period is provided by the NOW account experience in New England. Estimates of the percentage of individual demand deposits shifted to NOW accounts in the first year have generally been close to 20 percent. ${ }^{17}$ If the experience with ATS accounts is the same, Ml growth would be reduced by 4.2 percentage points in the first year, while growth of $\mathrm{Ml}^{\circ}$ and $\mathrm{M} 2$ would be increased by 0.8 percentage points, other things remaining constant.

\footnotetext{
17See The Money Manager, October 16, 1978, p. 28 which reports this percentage as consistent with the shift of demand deposits into NOW acconnts in New England. A similar percentage also is expected at the largest commercial bank in the nation, American Banker, September 12, 1978, pp. 1, 15 .
}

\section{ATS, MONETAPV POLICY, AND THE ECONOMIC OUTLOOK}

Monetary aggregate growth affects the economy's growth of output, employment, and prices, and influences financial market developments domestically and abroad. Consequently, the Federal Open . Market Committee (FOMC) in recent years has set ranges for growth rates of monetary aggregates which are intended to be consistent with national economic objectives. The FOMC monitors monetary aggregate growth and economic developments in order to assess the effectiveness of their actions and to decide whether to alter monetary policy. The FOMC does not directly control the M1 or M2 aggregates; instead, they control the size and composition of the total assets of the Federal Reserve System. Actions which change System assets, however, have a direct impact on the base, the total of financial assets available to be held as currency by the public or as reserves in the commercial banking system. The rate of growth of the base is the prime determinant of the growth of monetary aggregates.

The transition to ATS will affect the expected growth rates of monetary aggregates resulting from any given growth path for the source base. Since $\mathrm{M}^{*}$ and $\mathrm{M} 2$ will tend to grow faster as ATS balances rise to the desired proportion of the public's transaction balances, maintaining a given rate of growth of these aggregates will require slower growth of the source base. Alternatively, since ATS will tend to reduce M1 growth given a growth path of the base, maintaining a given rate of $\mathrm{MI}$ growth would require faster growth in the base. Another effect of ATS is to widen the disparity between M1 and M2 growth which can be expected during the transition period. The transition to ATS will lower MI growth and raise $\mathrm{M} 2$ growth independently of FOMC actions which change the source base.

The October change in the FOMC's mnounced MI growth range from that announced in July of last year partly rellected this development. In February, April, July, and October of 1978, the FOMC determined one-year ranges for $\mathrm{M} 1$ and $\mathrm{M} 2$ growth. The ranges determined in July were the same as those of February and April, calling for M1 growth in the coming year of 4 to 6.5 percent and for $M 2$ growth of 6.5 to 9 percent. The one-year period specified in July was from II/ 78 to II $/ 79$. In October the FOMC lowered the M1 growth range for the coming year (III/78 to III/79) to 2 to 6 percent, while leaving the $\mathrm{M} 2$ growth range unchanged. The difference be- 
tween the midpoint of the M2 range and the midpoint of the M1 range widened from 2.50 percentage points for the second-quarter ranges to 3.75 percentage points for the third-quarter ranges. In comparison, the impact of ATS on this differential growth of $\mathrm{M} 2$ and $\mathrm{M} 1$ (or $\mathrm{M1}^{*}$ and $\mathrm{M} 1$ ) is 0.74 percent for each one percentage point rise in $\mathrm{d}$.

The switch to ATS balances could also have a significant impact on the interpretation of monetary actions. During the transition to ATS, the growth of M1 will tend to slow while the growth of $\mathrm{Ml}^{\circ}$ and M2 will receive a positive stimulus. If the thrust of monetary actions is assessed by the resulting growth rates, conflicting signals about the direction of policy will result.

Since $\mathrm{MI}^{*}$ is a more accurate measure of currency plus checkable deposits, interpreting a slowing of M1 growth during the transition period is difficult unless one knows the extent of the shift from demand deposits into ATS deposits. Table V illustrates the relationship between the one-year growth of $\mathrm{MI}$ and $\mathrm{MI}^{*}$ (from III/78 to III/79) after the introduction of ATS, under various assumptions of the percentage of demand deposits that shift into ATS accounts. Again, other factors which would affect the difference between $\mathrm{M} 1$ and $\mathrm{MI}^{*}$ growth are held constant. $^{18}$

As shown in Table $\mathrm{V}$, the $\mathrm{Ml}$ " growth rate associated with any $\mathrm{M} 1$ growth rate is 1.3 to 7.5 percentage points higher for a 5 to 30 percent shift of eligible deposits, respectively. For a shift of 20 percent of eligible deposits, an Ml growth range of 2 to 6 percent corresponds to an $\mathrm{Ml}^{*}$ growth range of 7 to 11 percent, other factors remaining the same. Consequently, M1 growth of 2 to 6 percent does not necessarily represent a slowing of the growth of currency plus checkable deposits after the introduction of ATS; it could, in fact, represent an acceleration.

Most important, the interpretation of growth rates of monetary aggregates in assessing the prospects for inflation and recession is affected by the introduction of ATS. For example, consider two hypotheses concerning the impact of monetary actions on the economy. The first hypothesis is that inflation is a monetary phenomenon, so that changes in the rate of money growth result, with a long lag, in alterations of the inflation rate. The second hypothesis is

\footnotetext{
18The resulfs reported in Table $\mathrm{V}$ are unaffected by whether or not some portion of ATS balances is held for savings purposes only.
}

\begin{tabular}{|c|c|c|c|c|c|c|}
\hline \multicolumn{7}{|c|}{ 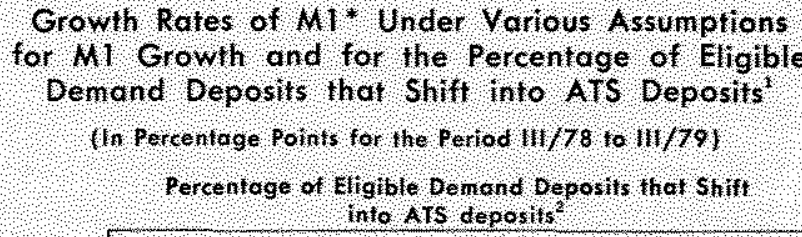 } \\
\hline Mowth & $(15 \%$ & $10 \%$ & $15 \%$ & $(0.6 \%)$ & $\begin{array}{l}25 \% \\
(8,5 \%)\end{array}$ & $\begin{array}{r}30 \% \\
10.2 \% 1\end{array}$ \\
\hline$-4 \%$ & 27 & 1,5 & 0,2 & 1,0 & 23 & 3.5 \\
\hline $3 \%$ & 17 & 0.5 & 08 & 20 & 3. & 48 \\
\hline $2 \%$ & 07 & 0.5 & 18 & 3.0 & 4,3 & 3.5 \\
\hline $4 \%$ & 03 & 15 & 28 & 40 & 5.3 & 6.5 \\
\hline $0 \%$ & 13 & 25 & 30 & 5.0 & 63 & 75 \\
\hline $1 \%$ & 23 & 3.5 & 48 & 60 & 73 & 8.5 \\
\hline $2 \%$ & 33 & 4,5 & 58 & 70 & 83 & 9.5 \\
\hline $3 \%$ & 4,3 & 5.5 & 68 & 80 & 93 & 105 \\
\hline $4 \%$ & 5.3 & 05 & 78 & 9.0 & 10.3 & 115 \\
\hline $5 \%$ & 63 & 75 & 8.8 & 100 & 11,3 & 125 \\
\hline $6 \%$ & 78 & 85 & 98 & 110 & 123 & 135 \\
\hline $7 \%$ & 8,3 & 9.5 & 10.8 & 120 & 13,3 & 145 \\
\hline $8 \%$ & 93 & 10.5 & 118 & 13,0 & 143 & 15,5 \\
\hline
\end{tabular}

This abie indicates an effect of $\mathrm{MTS}$ and is onl llubtrat ve of the

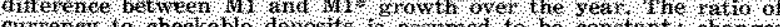

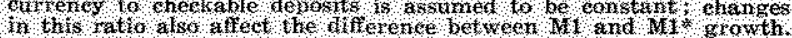

the percentages that are mplled by these fighres for the proportion of totat denand depesits whieh shift inte ATS deposits are stown in parcrtheses.

that a sharp slowdown in the rate of money growth relative to its recent trend rate of expansion is a primary cause of recession. Empirical assessment of the hypotheses often focuses upon the growth rate of $\mathrm{Ml}$, the monetary aggregate most sensitive to the ATS innovation.

A simplified version of the hypotheses in the context of the economic outlook for 1979 can be used to contrast the situation with and without ATS. Through the third quarter of 1978 (pre-ATS), the trend rate of growth of Ml over the previous five years had been 6.2 percent, but in the two years prior to ATS, M1 growth was at the highest rate ( 8 percent) in post-World War II history. Given this view, a contimuation of the 8 percent annual rate of M1 growth would continue the acceleration of the inflation rate. Since money growth would exceed its past trend rate, no monetary-indiced recession would occur. On the other hand, if Ml growth were to slow to perhaps a 4 percent rate or less for at least six months, the associated slowing in the growth of demand for goods and services could be large enough to produce a 
recession. If such a slowing in $\mathrm{Ml}$ growth were maintained, the accelerating trend of monetary expansion would tend to slow gradually and then reverse, so the inflation rate could be expected to slow in future years.

Now suppose that the hypotheses above are correct and that the transition to ATS is as large as 20 percent. If observed Ml growth were to slow to a 4 percent rate over the year, it would not involve the restrictive implications above. Indeed, this "slow" ing" of M1 growth would be deceptive since M1" could be growing at a 9 percent rate, faster than the record 8 percent rate of growth of currency plus checkable deposits over the two years ending in the third quarter of 1978 (Table V). If $\mathrm{M} 1$ ) has the same implications for the economic outlook as M1 formerly possessed, a sharp slowing of M1 growth over the first year of ATS could occur without recessionary implications. Indeed, given the assumptions used in Table V, a sharp slowing of M1 growth could be required for $\mathrm{Ml}^{*}$ growth to match the record rate of M1 growth in the prior two years, depending on the extent to which individuals adopt ATS accounts.

\section{CONCLUSION}

The introduction of ATS accounts at commercial banks may have substantial impacts on the behavior of monetary aggregates and their implications for economic developments over the year. The effects will depend upon the extent to which individuals switch from demand deposits to ATS savings accounts. The primary source of difficulty in controlling and interpreting monetary aggregate behavior is the existence of differential reserve requirements for checkable deposits held in ATS savings accounts and those held as demand deposits. Notwithstanding this problem, the definition of $\mathrm{M1}$, by excluding checkable savings balances, implies that MI growth will tend to slow during the transition to ATS, independently of changes in monetary actions and without necessarily altering the economic outlook. Should the Federal Reserve System adopt the new definition of MI recently proposed by the Federal Reserve Board staff, the interpretation of Ml as a measure of currency plus checkable deposits would cease to be affected by ATS, but effects due to differential reserve requirements would remain.

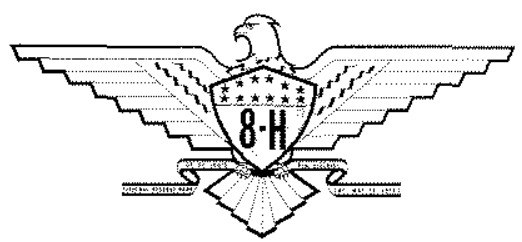

